\title{
Men's health in question: seeking assistance in primary health care
}

\author{
Max Moura de Oliveira ${ }^{1}$ \\ Donizete Vago Daher ${ }^{2}$ \\ Jorge Luiz Lima da Silva ${ }^{2}$ \\ Silvânia Suely Caribé de Araújo Andrade ${ }^{1}$
}

${ }^{1}$ Coordenação Geral de Doenças e Agravos Não Transmissíveis, Departamento de Vigilância de Doenças e Agravos não Transmissíveis e Promoção da Saúde, Secretaria de

Vigilância em Saúde, Ministério da Saúde. SQN 409/Bloco C/301, Asa Norte. 70857-030 Brasília DF

Brasil.

maxomoura@gmail.com

${ }^{2}$ Escola de Enfermagem Aurora de Afonso Costa, Universidade Federal

Fluminense.

\begin{abstract}
The scope of this study was to analyze the socio-demographic profile, morbidity and frequency of seeking of adult men enrolled in a Family Doctor Program for health care in Niterói in the State of Rio de Janeiro. It is a cross-sectional study using secondary data, files and records of the first care visit in November 2003 through August 2009. The frequencies of the variables studied and the prevalence rates among those who sought and those who did not seek attention were calculated. Among the 323 men registered, 56\% sought attendance. The main reason given for the first visit was a routine appointment. It was observed that 43 men were overweight, 26 were obese and 44 had abnormal blood pressure. The profile of the men who sought and those who did not seek care presented statistically significant differences ( $p<$ $0.05)$ for: age, education level, social security and reference to morbidity at the time of registration. Older men with social security reporting some morbidity sought health services more often. It is necessary to broaden the studies to acquire more input for public health actions and policies that contemplate this population segment and its specificities.
\end{abstract}

Key words Man's health, Primary health care, Gender, Health 


\section{Introduction}

According to the census 2010 data, the brazilian population is made up for $49 \%$ of men; of these $46.8 \%$ are in adulthood (25-59 years) ${ }^{1}$. Epidemiological data show that two thirds of people who die in Brazil are male, accounting for approximately $60 \%$ of deaths in this country ${ }^{2}$.

In the period between 2008 to 2010, the leading cause of death in the adult male population was road injury (average annual rate of 112, 3 deaths per 100000 men), followed by cancers (average annual rate of 111, 5 deaths 100000 men) and violence (average annual rate of 112.0 deaths per $100000 \mathrm{men})^{3}$. The risk factors associated with chronic diseases monitored by telephone survey Vigitel in the period 2006-2011 showed an increased prevalence of overweight, obesity, and diabetes among men ${ }^{4}$.

The Unified Health System (SUS), throughout its history, develops policies that subsidize health interventions for specific groups. In this perspective, in 2008, The National Comprehensive Attention to Men's Health Policy was formulated (PNAISH) in order to guide the actions of health, encourage self-care and especially in recognition of health as a basic social right and citizenship of all Brazilian men ${ }^{5}$.

The illness and self-care are considered as little valued actions by men, this keep them away from the access to health services ${ }^{6}$. PNAISH and the National Primary Care Policy (PNAB) aim to strengthen the actions and services in networks of care and thus developing the main objective of this policy is "to promoting health actions that contribute significantly to understanding man's singular reality in his several socio-cultural and political-economic contexts and respecting the different levels of development and organization of local health systems and management types, enabling the increase in life expectancy and reducing the rates of morbidity and mortality from preventable and avoidable causes in this population"

In Niterói, the current model of primary care is the Family Doctor Program (FDP), which was initially implemented in areas of low income, with a view to the clientele to the ascription of primary care service. Community organizing is co-manager, along with the government, which is responsible for contracting professionals FDP: engineers, supervisors, basic staff (physicians and nursing assistants). The health service program is organized into modules that are divided into mi- cro areas (sectors), which comprise approximately 1.200 people. The geographical coverage area of each sector must allow access of all households and people to this module ${ }^{7}$.

Therefore, this study aimed to describe the socio-demographic profile, morbidity and frequency of search for a health service of adult men in a sector of the FDP of Niteroi - RJ, and analyze the differences between individuals who sought and those who did not seek care.

\section{Method}

It is a cross-sectional study using secondary data, held in a sector Module Matapaca of the Family Doctor Program (FDP) in Niterói-RJ. The study population consisted of men aged 25-59 years old, according to the PNAISH recommended age range, registered in the sector. Data from the registry of the same individual from the first service in November 2003, when it started the registration of this sector, until August 2009, date of beginning of fieldwork, were collected. This search occurred from August to December 2009.

The following variables were collected : race / (white and brown / black) color skin, marital status (with or without a partner), age, social insurance (yes and not), schooling (0-8, 9-11 and 12 or more) and distance from home to the health services (Up to $2 \mathrm{~km}$ and over $2 \mathrm{~km}$ - With the exception of a small area that was later ascribed to the studied sector, the entire area is located around the module); reference to some morbidity at registration (yes and no); the frequency of visits to health service and reason for seeking treatment. In the category of those who receive Social Security are the retirees and those who receive unemployment benefits. For the variables that might have temporal variation was collected last recorded information. Data were collected from the medical records through a standardized instrument by a single researcher.

We analyzed the data consistency using Microsoft Excel 2003 and Epinfo 3.5.3 Program was used for statistical analysis. Frequencies and prevalence ratios and their respective confidence intervals (95\% CI) were calculated.

The research was approved by the Research Ethics Committee of the Universidade Federal Fluminense. The service managers were informed about the objectives of the study and agreed with it. There were no conflicts of interest to this work. 


\section{Results}

There were included 323 men enrolled in the Family Doctor Program (FDP) in a sector Module Matapaca in Niterói-RJ, representing approximately $27 \%$ of registrations in this sector. One hundred and forty-three men (44\%) were registered; and in the period of the five years of the study they have never been in the health service; however, it is noteworthy that 24 of them reported complaints at registration.

One hundred and eighty men (56\%) sought care in the health service at some time during the five years, and the main reason to the first attendance at the clinic was routine visit (72\%) with an average of 10 visits from November 2003 to August 2009, whereas the highest proportion $(42 \%)$ to the subsequent attendances was also routine visits, however, the average number of visits due to follow-up was statistically higher $($ mean $=17$ visits $)($ Table 1$)$.

According to the observed data, 43 men (28\%) were overweight (BMI $\geq 25 \mathrm{~kg} / \mathrm{m} \mathrm{2}$ ) and $26(17 \%)$ were obese (BMI $\geq 30 \mathrm{~kg} / \mathrm{m} 2)$. The frequency of abnormal blood pressure $(\mathrm{mmHg} \geq$ $140 x 90)$ was $26 \%(\mathrm{n}=44)$. Among those seeking care $(\mathrm{n}=180), 36 \%$ reported some health complaint, however, 119 enrolled men (83\%) who never sought health services of the Module Matapaca FDP reported no disease at registration.

The men's profile who sought and those not seeking care at the health service showed statistically significant differences $(\mathrm{p}<0,05)$ to: age, education, social security and reference to morbidity at registration. The average age of men who sought care at a health services (41 years) was higher than those who had not sought (Table 2).

Those who have $0-8$ years of schooling (PR: 5.02, 95\% CI: 2.0 to 12.61 ) and 9-11 (PR: 3.98, $95 \%$ CI: 1.57 - 10.11) showed higher frequency in the demand for care than those with more than 12 years of study. Social Security benefits was associated with seeking treatment (PR: 1.37, 95\% CI: 1.12 to 1.68 ). It is noteworthy that $36 \%$ (n $=65$ ) of individuals who sought treatment reported some morbidity, with an PR of 1.49 (95\% CI: 1.24 to 1.78 ) than those who have not sought health service. The following characteristics were not statistically associated with the search for service: race / color skin, marital status and distance of residence (Table 2).

\section{Discussion}

Results are consisted with expectations, men reported having some health problems at registration were those who sought more health services, as well as older men, who are at a stage in life where health tends to weaken, and those who reported having retirement.

The adult men's profile registered in a sector of the Family Doctor Program of Niteroi-RJ has shown that about $40 \%$ of them did not seek health care. This not seeking treatment in primary care may reflect the social role built for the man in that masculinity is linked to values or attributes such as strength, aggression and competitiveness that have been socially constructed, helping to determine, for example, the profile morbidity and mortality of these subjects ${ }^{8}$.

One hypotheses of non-use of the service is that health service made no active search for registered users and that both men registered as men residents of the local who are not registered, making use of other health services.

In addition, fewer men seek health services of primary care than women, and they tend to choose for hospital services, private practices and emergency care or emergency services ${ }^{2}$.

Table 1. Classification by reason of service provided to the men registered in a module sector of the Family Medical Program in Niteroi-RJ, November 2003 to August 2009.

\begin{tabular}{lrrrrr}
\hline \multicolumn{1}{c}{ Reason of attendance } & n & $\%$ & Average & Min-Max & P value $^{*}$ \\
\hline First service $(\mathrm{n}=180)$ & 129 & 72 & 10 & $(1-61)$ & $<0.01$ \\
Clinical routine & 51 & 28 & 8 & $(1-50)$ & \\
Emergency service & & & & $(1-34)$ & $<0.01$ \\
Subsequent attendances $(\mathrm{n}=180)$ & 76 & 42 & 6 & $(5-61)$ & \\
Routine consultation & 59 & 33 & 17 & $(1-23)$ & \\
Assisted & 44 & 25 & 6 & & \\
Emergency service & & & &
\end{tabular}

Kruskal-Wallis H 
Table 2. Socio-demographic and morbidity of men enrolled in a Module Sector of the Family Medical Program in Niteroi-RJ, November 2003 to August 2009.

\begin{tabular}{|c|c|c|c|c|c|}
\hline \multirow{3}{*}{ Features } & \multicolumn{4}{|c|}{ Procurou atendimento } & \multirow[b]{3}{*}{ Valor de p } \\
\hline & \multicolumn{2}{|c|}{ Sim } & \multicolumn{2}{|c|}{ Não } & \\
\hline & Média & Mín-Máx & Média & Mín-Máx & \\
\hline Age, in years $(n=323)$ & 41 & $(25-59)$ & 38 & $(25-59)$ & $<0.01^{*}$ \\
\hline \multirow[t]{2}{*}{ Attendances $(\mathrm{n}=143)$} & 9 & $(1-61)$ & - & - & - \\
\hline & $\mathbf{n}$ & $\%$ & $\mathbf{n}$ & $\%$ & RP (IC95\%) \\
\hline \multicolumn{6}{|l|}{ Color $(\mathrm{n}=123)$} \\
\hline White & 64 & 52 & 1 & 100 & $0.98(0.95-1,02)$ \\
\hline brown /Black & 58 & 48 & - & - & 1 \\
\hline \multicolumn{6}{|l|}{ Marital status $(\mathrm{n}=316)$} \\
\hline With a partner & 122 & 69 & 83 & 59 & $1.22(0.98-1.53)$ \\
\hline Without a partner & 54 & 31 & 57 & 41 & 1 \\
\hline \multicolumn{6}{|l|}{ Schooling, in years $(\mathrm{n}=318)$} \\
\hline $0-8$ & 114 & 65 & 62 & 43 & $5.02(2.0-12.61)$ \\
\hline $09-11$ & 57 & 33 & 54 & 38 & $3.98(1.57-10.11)$ \\
\hline 12 or more & 4 & 2 & 27 & 19 & 1 \\
\hline \multicolumn{6}{|l|}{ Social Safety $(\mathrm{n}=321)$} \\
\hline Yes & 100 & 56 & 55 & 38 & $1.37(1.12-1.68)$ \\
\hline No & 78 & 44 & 88 & 62 & 1 \\
\hline \multicolumn{6}{|c|}{ Distance Residence -PMF (N = 323) } \\
\hline Until 2 km & 170 & 94 & 133 & 93 & $1.12(0.72-1.76)$ \\
\hline More than 2 km & 10 & 6 & 10 & 7 & 1 \\
\hline \multicolumn{6}{|c|}{$\begin{array}{l}\text { Disease referred at the time of registration } \\
(\mathrm{n}=323)\end{array}$} \\
\hline Yes & 65 & 36 & 24 & 17 & $1.49(1.24-1.78)$ \\
\hline No & 115 & 64 & 119 & 83 & 1 \\
\hline
\end{tabular}

* T Student

In a study of gender it was found that the social construction of masculinity is directly related to the ways of perceiving and living the sick and care for the body. That, in turn, access and attendance to health services are directly related to the fact that men do not recognize themselves as patients ${ }^{8}$. Furthermore, the discipline of self-care has been incorporated into the women routine, and men are less worried with self-care?

Another study, which analyzed conceptions of health professionals about the demands and behaviors of the male population attended in the health services, pointed out that the presence of men is still fairly limited and the hurry, objectivity, fear and resistance, beyond difficulty of the relationship between healthcare professional and men are point-like factors that keep away men of health services ${ }^{10}$.

The demand for health services still is connected to a health problem, acute or chronic. Thirty-six percent of individuals who sought treatment reported some morbidity. Addition- ally, the findings of overweight, obesity and abnormal blood pressure in primary care, are presented as a warning, since they are directly associated with cardiovascular disease, hypertensive diseases and diabetes mellitus, these are among the most important causes of mortality in men ${ }^{2,5}$.

Data of Vigitel 2011, representative telephone survey of individuals over 18 years old from Brazilian capitals and the Federal District, described for the male population a prevalence of $52.6 \%$ overweight, $15.6 \%$ obese and $19.5 \%$ of hypertension. Overweight and hypertension tended to increase with age. In the present study, the frequency of obesity and hypertension showed higher proportions compared to data Vigitel ${ }^{4}$.

In a household survey conducted with 217 men, between 20 and 49 years old, enrolled to the Family Health Strategy in urban area of Juiz de Fora (MG), in 2006, , was observed a frequency of overweight/obesity of $43.3 \%$ and $24 \%$ of hypertension $^{11}$. Both this study and the Vigitel corroborate with data from our study, about the need to 
intensify health promotion strategies in the male population. We observed the existence of a significant number of men who have health problems mentioned in the registers and not seeking primary health services. Thus, identify the psychosocial factors related to greater vulnerability may contribute to building a culture of prevention ${ }^{12}$.

In our study, older men with less education and those who reported having social insurance were associated with the search for health care. The hypotheses that may explain these relationships are that men in working age and allocated in the labor market have difficulties in seeking care in primary care, both low schooling and to receive of social insurance are indicative of lower socioeconomic status of the subjects studied. People who have 12 years or more of schooling and income than five minimum wages were associated with having health insurance, clarifying the association found in this study ${ }^{13}$.

The timing of work activities are not compatible to the opening hours of the health services, since the time operation of health services overlaps the work ${ }^{14}$. There is a need to review the service offerings to men in working age, especially about their accessibility to the health services.

The provider role played by man creates difficulties to introduce self-care spaces. Beyond the issues of hours service provision, there is a need for changes in the strategies of health services, particularly in educational strategies for greater adherence of men to health facilities, and training / continuing qualification of teams of health professionals to meet the same $e^{15,16}$. As well as understanding the logic of attendance of men in the structural sphere that these services are offered as a whole ${ }^{17}$.

PAISH must consider the heterogeneity of the possibilities of being a man. Actions must safeguard the various needs and demands of the Brazilian male population without discrimina- tion $^{5,18}$; investing in an access movement that understands and meets the man in his uniqueness and specificities ${ }^{19}$.

In a study that sought to examine PAISH, from the perspective of the actors involved in its implementation, it was observed that the same has been thought as a guide to care to address men in reducing attention of urological problems however this policy is still vague and without details of how to proceed to meet these men. These different contexts must be considered in the implementation of policy for the effective and continuous engagement of the health professionals ${ }^{20}$.

There is the need to sensitize this population segment to use primary care as an entry in the Health System ${ }^{21}$. One strategy would be to establish partnerships with employers sectors such men to the workplace may be promotion and prevention environments, to address issues related to health care.

Study's limitations are: it has not been possible to describe the period of time between the registration of subjects and the first search for care, because there is not the deadline of the date of registration before. These data could contribute to the understanding of the frequency between the register and the search of health care. In addition, we considered only the attendances of medical consultations and inter records queries of the supervisors, since the attendances made by other professionals, such as nursing staff, were not recorded in medical records, underestimating numbers data on demand for care.

It highlights the importance of further studies with men who do not attend primary health care, in order to meeting their epidemiological profile, demands and health needs to build support to actions and health policies public that address this population segment and their specificities.

\section{Collaborations}

MM Oliveira, DV Daher, JLL Silva participated in the conception and design of the study. MM Oliveira, DV Daher, JLL Silva collaborated in analyzing and interpreting the data, writing and critic review relevant to the intellectual content of the manuscript and final approval of the version to be published. 


\section{References}

1. Instituto Brasileiro de Geografia e Estatística (IBGE). Censo Demográfico e Contagem da População. Rio de Janeiro: IBGE. [acessado 2013 fev 20] Disponível em: http://www.sidra.ibge.gov.br/bda/tabela/listabl.asp? $\mathrm{c}=1378 \& \mathrm{z}=\mathrm{cd} \& \mathrm{o}=7$

2. Brasil. Ministério da Saúde (MS). Secretaria de Vigilância em Saúde. Departamento de Análise de Situação em Saúde. Perfil da Saúde no homem. In: Brasil. Ministério da Saúde (MS). Saúde Brasil 2007: uma análise da situação de Saúde. Brasília: MS; 2007. p. 509-536.

3. Brasil. Ministério da Saúde (MS). DATASUS. [acessado 2012 jan 30]. Disponível em: http://www2.datasus.gov. br/DATASUS/index.php?area $=02$

4. Brasil. Ministério da Saúde (MS). Secretaria de Vigilância em Saúde. Secretaria de gestão Estratégica e Participativa. Vigitel Brasil 2011: vigilância de fatores de risco e proteção para doenças crônicas por inquérito telefônico. Brasília: MS; 2012.

5. Brasil. Ministério da Saúde (MS). Secretaria de Atenção à Saúde. Departamento de Ações Programáticas Estratégicas. Política Nacional de Atenção Integral à Saúde do Homem (princípios e diretrizes). Brasília: MS; 2008.

6. Korin D. Novas perspectivas de gênero em saúde. Adolesc Latinoam 2001; 2(2):67-79.

7. Hubner LCM, Franco TB. O programa médico de família de Niterói como estratégia de implementação de um modelo de atenção que contemple os princípios e diretrizes do SUS. Physis 2007; 17(1):173-191.

8. Gomes R. Sexualidade Masculina, Gênero e Saúde. Rio de Janeiro: Fiocruz; 2008.

9. Figueiredo WS, Schraiber LB. Concepções de gênero de homens usuários e profissionais de saúde de serviços de atenção primária e os possíveis impactos na saúde da população masculina, São Paulo, Brasil. Cien Saude Colet 2011; 16(Supl. 1):935-944.

10. Knauth DR, Couto MT, Figueiredo WS. A visão dos profissionais sobre a presença e as demandas dos homens nos serviços de saúde: perspectivas para a análise da implantação da Política Nacional de Atenção Integral à Saúde do Homem. Cien Saude Colet 2012; 17(10):2617-2626.

11. Eyken EBBDV, Moraes CL. Prevalência de fatores de risco para doenças cardiovasculares entre homens de uma população urbana do Sudeste do Brasil. Cad Saude Publica 2009; 25(1):111-123.
12. Alves RF, Silva RP, Ernesto MV, Lima AGB, Souza FM. Gênero e saúde: o cuidar do homem em debate. Psicol Teor Prat 2011; 13(3):152-166.

13. Instituto Brasileiro de Geografia e Estatística (IBGE). Pesquisa Nacional por Amostra de Domicílios. Um Panorama da Saúde no Brasil: acesso e utilização dos serviços, condições de saúde e fatores de risco e proteção à saúde. Rio de Janeiro: IBGE; 2008.

14. Gomes R, Nascimento EF, Araujo FC. Por que os homens buscam menos os serviços de saúde do que as mulheres? As explicações de homens com baixa escolaridade e homens com ensino superior. Cad Saude Publica 2007; 23(3):565-574.

15. Schraiber LB. Figueiredo WS, Gomes R, Couto MT, Pinheiro TF, Machin R, Silva GSN, Valença O. Necessidades de saúde e masculinidades: atenção primária no cuidado aos homens. Cad Saude Publica 2010; 26(5):961-970.

16. Machado MF, Ribeiro MAT. Young men's discourses regarding access to healthcare services. Interface (Botucatu) 2012; 16(41):343-355.

17. Gomes R, Moreira MCN, Nascimento EF, Rebello LEFS, Couto MT, Schraiber LB. Os homens não vêm! Ausência e/ou invisibilidade masculina na atenção primária. Cien Saude Colet 2011; 16(Supl. 1):983-992.

18. Couto MT, Pinheiro TF, Valença O, Machin R, Silva GSN, Gomes R, Schraiber LB, Figueiredo WS. Men in primary healthcare: discussing (in)visibility based on gender perspectives. Interface (Botucatu) 2010; 14(33):257-270.

19. Domingues PS, Daher DV, Pinto AA. Health education as a possibility for health promotion of men. Nurse UFPE 2012; 6(12):3034.

20. Gomes R, Leal AF, Knauth D, Silva GSN. Sentidos atribuídos à política voltada para a Saúde do Homem. Cien Saude Colet 2012; 17(10):2589-2596.

21. Duarte S, Oliveira J, Souza R. A Política Saúde do Homem e sua operacionalização na Atenção Primária à Saúde. Gestão e Saúde 2012; 3(1):520-530.

Article submitted 30/08/2013

Approved 26/10/2013

Final version submitted 31/10/2013 